\title{
TÁRSADALMI INNOVÁCIÓS LEHETŐSÉGEK A TURIZMUSBAN
}

\author{
Nagy Katalin \\ mesteroktató, Miskolci Egyetem, Marketing és Turizmus Intézet \\ 3515 Miskolc, Miskolc-Egyetemváros, e-mail: nagy.katalin@uni-miskolc.hu
}

\begin{abstract}
Absztrakt
A társadalmi innováció nem más, mint új megoldások kidolgozása és megvalósitása társadalmi problémák megoldása érdekében. A legtöbb magyar és nemzetközi szakirodalom a társadalmi marketinget és más, területfejlesztési megközelitéseket dolgoz fel, s csak ritkán vizsgálja a jelenséget a turizmussal kapcsolatban. Számos kutatás vizsgálódik a kérdéskörben a vállalkozások szemszögéböl (pl. Howards-Grenville et al 2014, Schrempf 2014), intézményi oldalról (pl. Dorado 2013, Zietsma és Lawrence 2010), vagy menedzsment, CSR és interszektorális partnerségi viszonyban (pl. De Bakker et al 2005). Mindemellett, találunk társadalmi innovációs jó gyakorlatot a turizmusban is, pl. a tematikus utak terén (pl. Lourens 2007). Jelen tanulmány a szakirodalmi áttekintés mellett a társadalmi innovációk turisztikai alkalmazási lehetöségeit veszi számba, bemutatva néhány jó gyakorlatot, eredményes példát, majd néhány hazai alkalmazási lehetöségre mutat rá a tematikus turizmusfejlesztés területéröl.
\end{abstract}

Kulcsszavak: innováció, turizmus, tematikus turizmusfejlesztés, társadalmi innováció

\begin{abstract}
Social innovation is the process of developing and implementing new solutions to social problems. Most of the Hungarian and international papers apply social marketing and other spatial development approaches, and just rarely examine this question in connection with tourism. Many research deals with this issue from entrepreneurial viewpoints (e.g. Howards-Grenville et al 2014, Schrempf 2014), or examines institutional questions (e.g. Dorado 2013, Zietsma and Lawrence 2010), or management, CSR and inter-sectoral partnerships (e.g. De Bakker et al 2005). However, there are good examples for social innovations in tourism, too, for instance in route-based tourism (e.g. Lourens 2007). This paperbesides giving a general literature review - intends to present some possibilities of social innovation application in tourism, by collecting best practices, successful results, then to point out some national cases in the field of thematic tourism development.
\end{abstract}

Keywords: innovation, tourism, thematic tourism development, social innovation

\section{Bevezetés}

A társadalmi innovációk megjelenését, illetve lehetőségeit a turizmusban személyes indíttatásból kezdtem vizsgálni. Doktori disszertációm a kulturális útvonalak témakörével foglalkozik, melyeknél a menedzsment-szervezet megléte vagy hiánya alapvető a müködés és a sikeresség szempontjából. Ennek kapcsán merült fel a kérdés, hogy ezek a szervezetek vajon müködhetnek-e társadalmi vállalkozás formájában, amennyiben a turizmus azon hatását tekintjük, hogy mennyire vonja be a helyi közösségeket a fejlesztésbe, vagy mennyire járul hozzá a helyiek jólétéhez, kiegészítő jövedelemhez jutásukhoz. Ugyanakkor az is világossá vált, elsősorban a bemutatott nemzetközi példák alapján, hogy 
nem mindig „van új a nap alatt”, hasonló példák hazánkban is születtek már (pl. Pesca turizmus és falusi turizmus, vendégasztal között felismerhető hasonlóság), legfeljebb nem ilyen szempontok szerint kerültek elemzésre. Így aztán a lehetséges új típusú együttmüködések felé fordult az érdeklődésem, s mutatok be olyan saját kutatási eredményeket, melyek e területen születtek.

\section{Szakirodalmi áttekintés}

A turizmus a világgazdaság legfontosabb szolgáltatási ágazata. Ma már e területen is az élménygazdaság fogalmáról beszélünk - ahol a mély, egyedi, autentikus élmények a látogatók szempontjából alapvető fontosságúak. Az élménygazdaság jellemzői: a termékek élményként való fogyasztása, a modern technológiák alkalmazása az élmények generálásában, a fogyasztók aktív bevonása, individualizáció, az élmények a fogyasztók emlékeiben raktározódnak el (Stasiak, 2013). Az élmény az értékteremtés forrása. Az élmény a turizmus veleszületett sajátossága - miközben a turisták tudatosabbak, mint valaha bármikor, előzetes ismereteik a felkeresni kívánt desztinációról magasak, helyi és autentikus szolgáltatásokat igényelnek és keresnek. A vágyott élmény megjelenhet izgalom, kaland, új információ és tudás, új képességek, esztétika, társaság, egzotikum vagy számos egyéb formában (Michalkó - Rátz 2005, Puczkó - Rátz 2011). A kereslet a kultúra és örökség irányába mozdul el, a turisták arra vágynak, hogy kipróbálják, megkóstolják, érezzék, váljanak a részévé az attrakcióknak, ahelyett, hogy puszta szemlélődők legyenek. Az ilyen atmoszféra, kreativitás és életmód mind része a kulturális örökségnek, csakúgy, mint a hagyományok és a történelem. A 21. század turizmusát „posztmodern turizmus”-nak vagy „új turizmus”-nak nevezzük, melyet 3E-vel lehet jellemezni, a korábbi, 20. századi tömegturizmus 4S-e helyett: education (nevelés), entertainment (szórakozás) és excitement (izgalom) - így jelent meg az „edutainment” új fogalma (Stasiak, 2013). Boswijk és társai (2005) szerint, a turisták jelentéssel teli élményeket keresnek, melynek lényegi eleme az innováció, s a második generációs élmények a co-creation elvére épülnek. A közös értékteremtés olyan termékeket és szolgáltatásokat eredményez, ahol a turista maga is része ennek a folyamatnak (Prahalad - Ramaswamy, 2004). Az örökség - és különösen a szellemi örökség - került a kulturális turizmus fejlesztésének fókuszába, különös tekintettel a helyi közösségekre, azok hagyományaira, szokásaira, népzenéjére és történeteire (Schlüter, 2012), ezekre épül a helyi identitás és a helyi közösségek folytonossága (Pedersen, 2004). Ezzel el is érkeztünk a lokalitás kérdéséhez, a helyi közösségek bevonásához, melyek a helyi társadalmat jelenítik meg, teljes kulturális, természeti és gazdasági környezetükkel - pozitív erősségeikkel és negatív problémáikkal - együtt; s ez már a társadalmi innováció terepe. A kérdés az, hogy sikerülhet-e a kulturális örökségturizmus és a társadalmi innováció lehetőségeinek kombinálása. A kérdéskört részletesen is körüljárja Kovács (2014).

A társadalmi innováció lényege új elképzelések, termékek, szolgáltatások és modellek kialakítása és megvalósítása társadalmi szükségletek, kérdések megoldása érdekében, melyek révén új típusú társadalmi kapcsolatok és együttmüködések jöhetnek létre (European Commission 2013). Az ilyen típusú fejlődés munkalehetőséget, infrastrukturális és pénzügyi erőforrásokat jelent, különösen a marginalizált vidéki térségekben (Alkier et al. 2015, Butler-Hinch 2007, Sloan et al 2014, Zeppel 2006, in Alkier et al 2017). Benedek és szerzőtársai (2015:7, 2016:16) úgy találták, hogy a társadalmi trendek változásai az innovációra is hatással vannak: "Egyrészt az ipari társdalomból a tudás- és szolgáltatásorientált társadalomba való átmenet hatására arányeltolódás következett be. Másrészt a perifériális helyzetü települések és közösségek természetes igénye a felzárkózás, amelyhez jelentősen hozzájárulhatnak a helyi ötletek, ill. újszerü kezdeményezések." Ezen koncepció és más meghatározások alapján, a következő definíciót adják: "A társadalmi innováció adott közösség problémáinak megoldására ad új, vagy újszerű választ a jól-lét javítása érdekében. A társadalmi 
innovációs potenciál pedig azon potenciális képességek összessége, amely a társadalmi innovációk létrehozását segíti" (Benedek et al, 2016:16). Az OECD gazdasági szempontú definíciója szerint: „Fogalmi, folyamat vagy termék-változás, szervezeti változások, új pénzügyi megoldások, az érintettek és területek közötti új típusú kapcsolatok" (OECD 2009).

A nemzetközi szakirodalomban a társadalmi innováció számos megközelítésével találkozhatunk; például szervezeti változások - különböző, ellentétes érdekekkel rendelkező szereplők és intézmények interakciója (Rittel - Webber, 1973), veszélyek és lehetőségek a vállalkozások számára - a vállalkozások maguk is pozitív vagy negatív hatást gyakorolnak a társadalmi és környezeti tényezőkre (Howard-Grenville et al, 2014, Schrempf, 2014). Hasonlóan, intézményi kutatások is foglalkoztak a társadalmi innovációval (Dorado 2013, Zietsma - Lawrence 2010), míg mások a menedzsment szempontokat, a CSR-t, vagy az inter-szektorális együttmüködéseket vizsgálták (pl. DeBakker et al 2005). Ugyanakkor viszonylag kevés irodalom kezeli a társadalmi innovációt, mint a turizmusfejlesztés eszközét, vagy vizsgálja annak lehetőségeit a turizmusban.

A fenntartható innovációk vizsgálata az elmúlt húsz évben nyert teret a turizmusban (Alkier et al, 2017). A 2008-2010-es gazdasági válságig a turisztikai ágazatot is az igen gyors növekedés, az információáradat, a digitalizáció terjedése, a robotizáció és smart technológiák fejlődése miatti munkaerőpiaci átrendeződés, a migráció és a globalizáció jellemezte. A turisztikai desztinációk szolgáltatóinak ezért új üzleti modellekre van szükségük, mely a fenntarthatóság és a „sharing economy” gondolatát hordozza, Az új üzleti modell alapja a tudás kell, hogy legyen; egyének, szervezetek és hálózatok, ötletek és erőforrások összekapcsolását biztosító lehetőségekkel. Ebbe a társadalmi innováció is beletartozik. Az ennek keretében javasolt új megoldások, modellek hatékonyabbak, fenntarthatóbbak, vagy „csak” egészen újszerüek, a létrehozott érték elsősorban a társadalom, a helyi közösségek érdekeit szolgálják, mintsem az egyénekét (Stanford Business School 2017, in Alkier et al, 2017). A cél: társadalmi érték létrehozása.

A turizmus fontos szerepet játszik a társadalmi és gazdasági fejlődésben. Így, az innovatív megoldásoknak előnyöket és értékeket kell jelenteniük nem csupán a turisták, hanem a helyi stakeholderek számára is. A társadalmi innovációs megoldások a turizmusban fontos fejlődési faktort jelentenek, a fogyasztó-orientált nézőpont helyett a közösségi-orientált aspektust képviseli, mely a közösség társadalmi tőkéjét hasznosítja. Egyúttal versenyelőnyt is jelenthet a desztinációk számára. Ugyanakkor több tudományterületet is érintenek, mely kapcsolat a társadalmi innovációk három fó dimenzióját jelenti (Mosedale - Voll 2017): (1) az innovációk az ismert faktorok új kombinációja, (2) a gyakorlati megoldás túlmutat a szervezeti vagy diszciplináris határokon, (3) maga mögött hagyja az új kapcsolatok kényszerét korábban elkülönült személyek és csoportok között.

Az új interakciók a technológiai innovációkon keresztül befolyásolják a turisztikai keresletet és kínálatot, a turisták kulturális ágensekké válnak, különösen a „sharing economy” keretében. Ezek az innovációk gyakran párosulnak web-alapú technológiákkal, közösségi felületekkel - bár nem mindig pozitív a hatásuk (pl. Airbnb és az overturizmus kapcsolata bizonyos városi környezetben). A turizmusban a társadalmi innovációk elsősorban a területfejlesztés keretében jelennek meg, mint új típusú kapcsolatok kialakítása, munkahelyteremtés révén hátrányos helyzetűek bevonása, az általános jólét növelése, korábban abból kizártak bevonása a döntéshozásba és stratégia-alkotásba (Benevides et al, 2018).

A kulturális turizmus a világ turizmusának legdinamikusabban fejlődő ágazata. 2015-ben a nemzetközi utazások 40 \%-a volt kulturális jellegü (unwto.org), ez 2017-ben mintegy 516 millió utazást jelentett (Richards 2018). Nuryanti (1996) szerint, az örökség a társadalom kulturális hagyományainak és a helyi közösség identitásának része. Olyan múltbeli érték, melyet érdemes megőrizni az elkövetkező generációk számára (Hall - McArthur 1998). Swarbrooke (1994) meghatározása szerint, az örökség 
egyrészt a termék központi eleme, másrészt a fő utazási motiváció. Ma az örökségattrakciók jelentős túlkínálata tapasztalható, az örökségturizmus pedig erősen versenyképes és piac-orientált termékké vált; így a folyamatos fejlesztés és termékdifferenciálás a siker kulcsát jelenti. Poon (1989, in Light \& Prentice 1994) ezt a terméket ,új turizmus”-nak nevezi.

A tematikus utak természeti vagy mesterségesen létrehozott látnivalókat kötnek össze, egy bizonyos téma alapján, s ezek a látnivalók a közlekedés valamely formájának segítségével megközelíthetök. A fenntarthatóságra tekintettel, a tematikus utak az ismeretszerzést és a szórakozást egy időben szolgálják (Puczkó - Rátz 2011). A ,turisztikai útvonal” kifejezés jelentése, hogy különféle tevékenységeket és látnivalókat füznek fel egy bizonyos téma mentén, így ösztönözve a vállalkozásokat kiegészítő termékek és szolgáltatások nyújtására (Meyer et al, 2004, Clarke 2005). Így az útvonal alapú turizmus tulajdonképpen a turisztikai desztinációk fejlesztésének piac-vezérelt megközelítése (Lourens 2007). Kialakításuk koncepciója, hogy a tevékenységek és attrakciók egybefüzése kevésbé fejlett térségekben együttmüködést és partnerséget generál a közösségek és a szomszédos térségek között, így járulva hozzá a turizmuson keresztül a gazdasági fejlődéshez (Briedenhann - Wickens 2004, Gonda et al. 2016a, Gonda 2016b). A sikeres tematikus út kialakításban a partnerség arra utal, hogy a helyi klasztereken keresztül lehet versenyelönyhöz jutni (Telfer 2001, in Rogerson - Rogerson 2011).

A kulturális útvonalak az örökség újfajta megörzési és hasznosítási módját jelentik. Egyaránt jelentenek földrajzi utazást, ahogy különböző területeken, helyi egységeken haladunk keresztül, valamint mentális utazást is értékekkel, érzésekkel, érzelmekkel, élményekkel, melyek aztán a végső termékké állnak össze (Majdoub 2010). Kiemelkedően innovatív jellegüek a kulturális örökségvédelem területén belül (Martorell 2003).

A kulturális útvonalak koncepciója sajátságos módszertant igényel a kialakítás és müködtetés tekintetében, mely koordinált és integráltan menedzselt tevékenységek rendszerét jelenti. Az ICOMOS Kulturális Útvonalak Kartája szerint a módszertan elemei a következők:

1. kutatás - multidiszciplináris csoportok, közös kritérium-rendszer, koordináció;

2. finanszírozás - prioritások, együttmüködés, a magán- és közszféra bevonása;

3. védelem, értékelés, megőrzés - szigorú leltár alapján; autentikusság és integritás vizsgálata;

4. fenntartható hasznosítás, turizmus - térségfejlesztési eszköz is;

5. menedzsment - integrált módszerek, holisztikus megközelítés;

6. közösségi részvétel - a helyi lakosság bevonása.

\section{Jó példák a turisztikai társadalmi innovációkból}

Az Európai Unió beépítette a társadalmi innovációt az Innovative Union program formájában a Europe 2020 program céljainak elérése érdekében, mint a hét ún. zászlóshajó program egyike. Bár nem sokat, de találunk néhány jó példát a társadalmi innovációk turisztikai alkalmazásának területéről is:

1) WelcomeHOME: A projekt Porto (Portugália) városában került kidolgozásra, olyan társadalmi szolidaritási szövetkezet, mely a hajléktalanok társadalmi újra-integrálását támogatja oly módon, hogy a városban idegenvezetőként foglalkoztatják őket.

2) Pesca Tourism: A „Pesca-tourism” projekt célja, hogy a hivatásos halászokat bevonja a turizmusba, azáltal, hogy a turistákat saját hajójukon fogadják szabadidős - rekreációs tevékenységként, a halászat világának bemutatására.

3) ASSET, Gambia: Az ASSET (Association of Small Scale Enterprises in Tourism) programot 2000 áprilisában alapították azzal a céllal, hogy összehozza, támogassa és népszerüsítse a nagy számban a turizmusban tevékenykedő kisvállalkozásokat Gambiában. Célja a turisztikai kisvállalkozások támogatásán keresztül a fair kereskedelem, a fenntartható fejlesztés, mely 
hozzájárul a fizikai környezet megörzéséhez, a helyi közösségek társadalmi és gazdasági jólétéhez.

4) SmartDMO: A „Tourism Knowledge Community Platform” egy olyan digitális találkozási hely, ahol a turizmus köz- és magánszereplöi együttmüködése révén integrált turisztikai kínálatot alakíthatnak ki. A tudásmegosztás online fóruma.

Az útvonal-alapú fejlesztés legjobb példája az Európa Tanács Kulturális Útvonalak programja. Európa, mint turisztikai makro-régió, a világ első számú kulturális desztinációja, a történelmi és kulturális öröksége által generált nemzetközi utazások száma 2030-ra eléri a 750 milliót. A Tanács eredményei megállapodások formájában jelennek meg, ezek egyike a Kibővített Területi Egyezmény a Kulturális Útvonalakról (EPA), melyet 2010-ben fogadtak el. Célja, hogy megerősítse a már korábban létrejött kulturális együttmüködést, a fenntartható területi fejlődést és társadalmi kohéziót, olyan közös témákra koncentrálva, melyek szimbolikus jelentőséggel bírnak az európai egység, történelem, kulturális értékek és a kevésbé ismert desztinációk tekintetében. Az EPA dönt a Kulturális Útvonalak program stratégiájáról és a cím odaítéléséröl.

\section{Kutatási módszer és eredmények}

Kutatásaimban mind a kvalitatív, mind pedig a kvantitatív kutatási módszert használtam, az empirikus kutatásaim statisztikai módszerekkel elemezett turistamegkérdezések és szakértői kérdőívek, valamint mélyinterjúk voltak, utóbbiakat európai kulturális útvonalak menedzsereivel folytattam.

A kvalitatív kutatás eredményeként két konkrét esetben jutottam (illetve a második esetben több kutatótársammal együtt jutottunk) olyan megoldásra, ahol a társadalmi innováció új típusú együttmüködések formájában valósulhat meg.

Az első esetben a Csereháti Településszövetség koordinálásában megvalósult História-völgy projektet vizsgáltuk, mely jelentős térségfejlesztési hatással bírt. A természeti és történelmi emlékekben gazdag Bódva folyó és mellékvölgyei történelmi örökségét egy komplex turisztikai attrakcióként értelmező projektben 29 településen, mint magterületen kínálják az egy-egy történeti korhoz kötött, a történelmi örökséget és egy-egy helyi terméket fókuszba állító „időutazás” élményét. A kívánt hatást a korhü épületek, interaktív elemekkel rendelkező kiállítások, az aktív bekapcsolódásra lehetőséget adó programok, rendezvények, a korabeli viseletek, a gasztronómiai specialitások és a megvásárolható ajándéktárgyak egysége biztosítja. A koncepció szerint a História-völgy az egész Aggtelek-Edelény turisztikai desztinációs térség kulturális turisztikai kínálatának összefogására is kiterjeszthető lenne (a magterületen kívül további 18 településen halad keresztül az útvonal), sőt a későbbiekben a szomszédos határon túli részek is bekapcsolhatók.

Napjainkban a térség szolgáltatási színvonala nagyon alacsony. Gyakorlatilag azt mondhatjuk a térségről, hogy bár kiváló adottságokkal rendelkezik bizonyos típusú turizmus kialakítására és fejlesztésére, a látnivalókat valójában termékké kiegészítő szolgáltatások nem találhatók itt meg. Mindezt mintegy „megkoronázza” a helyi lakosság csendes beletörődöttsége, a szükséges gondolkodásmód és vállalkozókészség és az igazi közösségi erő hiánya (Nagy - Piskóti 2016). Kutatásaink és a helyi szereplökkel, fejlesztőkkel folytatott interjúink azt az elözetes feltételezést erősítették meg, hogy az a szervező erő, kompetencia-központként funkcionáló menedzsment szervezet hiányzik a térségből (1. ábra), amely a História-völgy mint útvonal müködtetését tudná megvalósítani.

Az útvonalba új életet kell lehelni - első lépésként a koncepciót kellene kiteljesíteni, mely elsősorban a térségi közösségfejlesztés - hálózatépítés - innovatív szervezet feladatokat jelentené. A megvalósítás első lépéseként egyfajta „virtuális TDM” létrehozását javasoltuk, mely mindenképpen igényli legalább egy, a szervezö-koordináló szerepben akár vállalkozói alapon fantáziát látó személy közremüködését. 
A legfontosabb feladat a szemléletformálás és a hálózatépítés, az így bevonható szolgáltatókra pedig már lehet ajánlati csomagokat kidolgozni. Ennek a szervezetnek a működése a társadalmi vállalkozások elvei mentén is elképzelhető, amennyiben a célokat ilyen értelemben fogalmazzuk meg az elején.

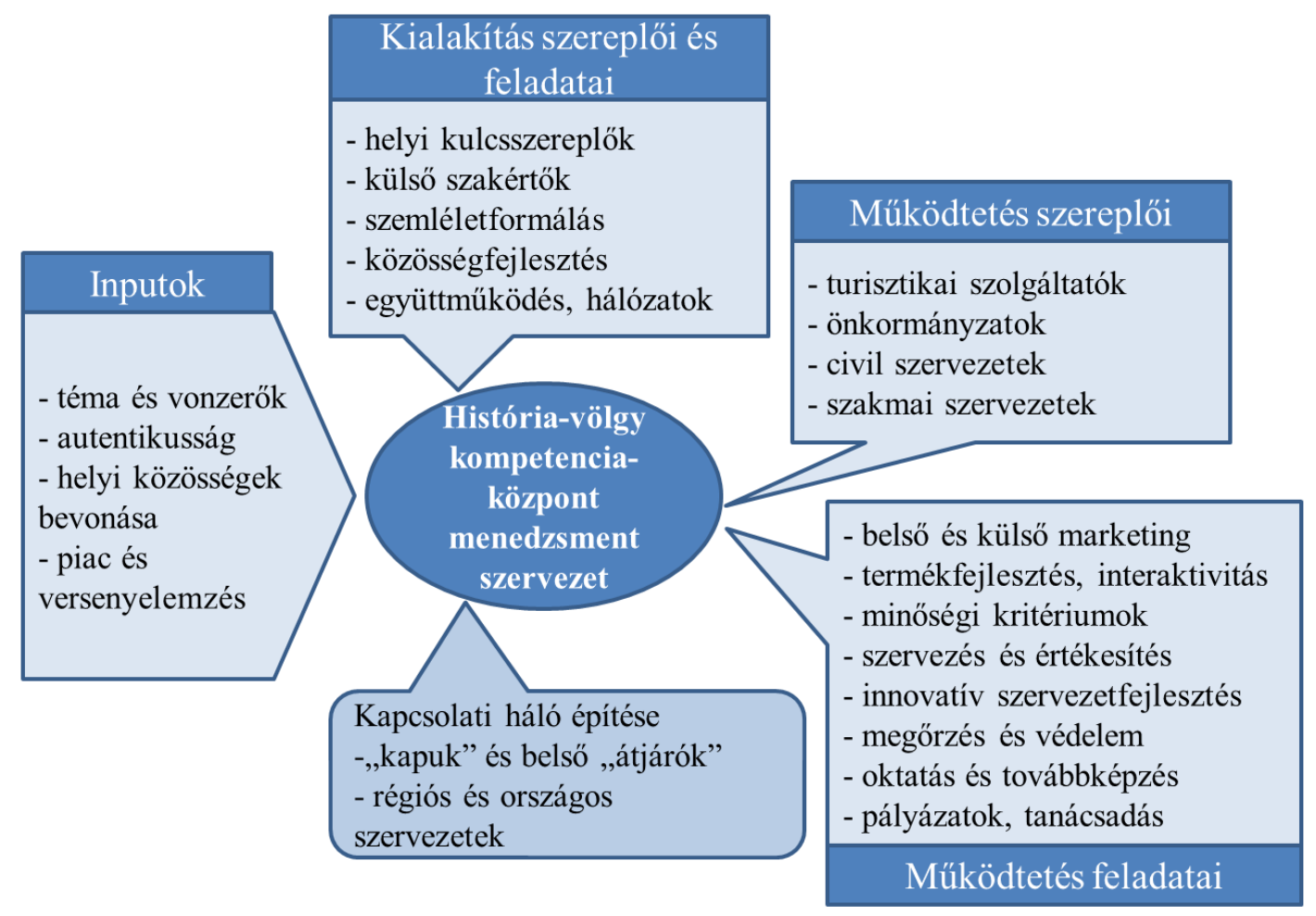

1. ábra. A História-völgy müködtetésére javasolt modell

A második esetben egy magyar megye számára készítettünk borút-fejlesztési koncepciót. A Turizmus Világszervezete szerint a bor- és gasztronómiai turizmus a kulturális turizmus része, mely a tevékenység-specifikus termékek csoportjába sorolható. A gasztronómiai turizmus olyan utazás, ahol egy desztináció felkeresésének teljes vagy részleges motivációja a helyi étel és/vagy italkínálat. Ebben a széles értelemben a gasztronómiai turizmus szándékos törekvés vonzó, autentikus, emlékezetes kulináris élmények szerzésére, akár nemzetközi, regionális vagy helyi turizmusban veszünk részt.

Magyarország igen gazdag gasztronómiai és borászati adottságokkal rendelkezik, az országban 22 történelmi borvidék található, melyek egyike, a Tokaji Borvidék az UNESCO Világörökségi helyszíne. Közelmúltbeli projektünk során egy kevésbé ismert és elismert megye számára javasoltunk megoldásokat a borturizmus fejlesztése érdekében, az útvonal-alapú turizmusfejlesztés alapelvei mentén. Kiindulásképpen az Európa Tanács Kulturális Útvonalak gyakorlatát használtuk, adaptálva a helyi sajátosságokra. Egy ún. kettős tematizálást alkalmaztunk, a megye kulturális és örökségelemeire építve. A kettős tematizálás a következőket eredményezte:

- klasszikus borutak, különböző célcsoportok és tevékenységek mentén, a borút szerbiai továbbépítésének lehetőségével,

- tematikus utak borkóstolókkal és borászatok felkeresésével kombinálva; az útvonalak helyi témákra építhetők, mint pl. ökoturizmus (nemzeti parkok és védett természeti területek), 
egészségturizmus (gyógyfürdők és termálvíz), kulturális turizmus (történelem, irodalom, népmüvészet, hagyományos gasztronómia vagy kézmüvesség, stb.). Jó lehetőség arra, hogy a bort és a borászat egyéb lehetőségeit más, meglévő turisztikai termékekkel kombináljuk.

Az innováció abban rejlik, hogy új típusú együttműködésre ösztönözzük a borászati és turisztikai szektor szereplöit, mivel jelenleg - ebben a térségben - a két szektor között nincs valós párbeszéd és együttmüködés, néhány eseti jellegü program kivételével. A témáról részletesen olvasható Piskóti és szerzőtársai (2019) Turisztikai és Vidékfejlesztési Tanulmányok c. folyóiratban megjelent cikkében.

A kvantitatív kutatás egy nagyobb léptékủ megkérdezés néhány eredményét mutatja be, mely a tematikus utak általános kérdéseit, a kialakítás és fejlesztés, valamint az együttmüködési és hálózatosodási problémákat vizsgálta. A társadalmi innovációk - mint lehetséges együttmüködési formák - a harmadik részben jelentek meg. A megkérdezés online történt, magyar turisztikai szakértők és szakemberek körében, a mintaszám $n=70$ volt.

Korábbi kutatásaim alapján (Nagy 2012, 2013a, 2013b) arra jutottam, hogy valamilyen, stakeholder menedzsment típusú szervezetre mindenképpen szükség van a tematikus utak koordinálását és sikeres müködtetését érintően, mint egyfajta kompetencia-központ, számos különbözö feladattal (2. ábra, Nagy - Piskóti 2013).

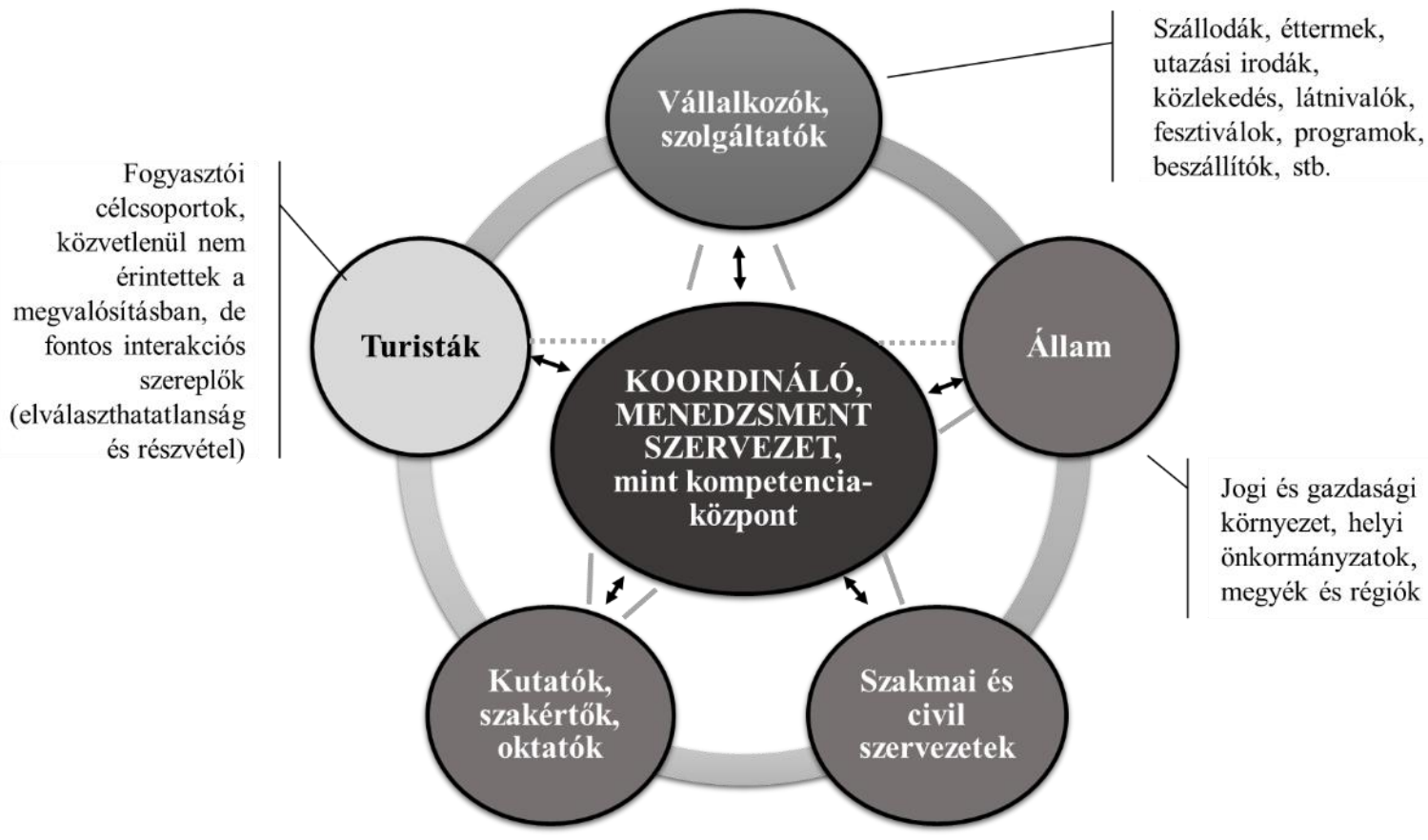

2. ábra. Kulturális útvonalak együttmüködési modellje

A meglévő útvonalakat tekintve számos szervezeti formával találkozhatunk, mint pl. egyesületek, non-profit társaságok vagy épp társadalmi vállalkozások. A kutatásban részt vett szakértők $73 \%$-a szerint a tematikus utak kialakítása és müködtetése különböző fázisaiban lehetséges ennek a központi szervezetnek különbözö formákban való müködtetése, ahogyan azt az 1. táblázat összefoglalja (a számok az említések gyakorisága, több válasz is megjelölhető volt):

A stakeholder management módszerét a turisztikai desztináció-menedzsment szervezetek (TDM) alapelve képviseli a legjobban, melyek - a szervezetépítés és tudásmegosztás alulról építkező 
megközelítését alkalmazva - müködési területükön széles körü hálózatépítésre képesek. Mivel a kulturális útvonalak alapja az együttműködés, ez a szervezet kiválóan alkalmas az útvonal menedzsment feladatainak ellátására is, ahogy az a fenti táblázatból is kitünik (legmagasabb említési szám: 36 a TDMek esetében). A szoros együttmúködés (collaboration) kapta a második legmagasabb értéket (31), ami azt jelenti, hogy ezeknek az új típusú hálózatoknak a turisztikai szektor valamennyi szereplöjét össze kell fogni, ami különösen jelentős elmaradott térségekben.

\section{1. táblázat. Együttmüködési formák a kulturális útvonalak különbözö fázisaiban}

\begin{tabular}{|c|c|c|c|c|c|c|c|}
\hline $\begin{array}{l}\text { Lehetséges együttmüködési } \\
\text { formák } \\
\text { Fázisok }\end{array}$ & $\begin{array}{l}\text { koncepció } \\
\text { kialakítása }\end{array}$ & $\begin{array}{l}\text { elökészítés, } \\
\text { audit }\end{array}$ & $\begin{array}{l}\text { szervezés, } \\
\text { termékfej- } \\
\text { lesztés }\end{array}$ & branding & $\begin{array}{l}\text { stratégia- } \\
\text { kidolgozás }\end{array}$ & $\begin{array}{l}\text { piaci } \\
\text { tesztelés, } \\
\text { belépés }\end{array}$ & $\begin{array}{l}\text { koordinációs } \\
\text { központ } \\
\text { müködtetése }\end{array}$ \\
\hline laza, informális együttmük. & 35 & 20 & 14 & 8 & 9 & 10 & 4 \\
\hline partnerség & & 21 & 31 & 16 & 25 & 16 & 24 \\
\hline $\begin{array}{l}\text { szoros együttmüködés } \\
\text { (kollaboráció) }\end{array}$ & 22 & 17 & 32 & 24 & 38 & 26 & 31 \\
\hline stratégiai szövetség & 18 & 12 & 19 & 20 & 36 & 15 & 26 \\
\hline klaszter & 15 & 12 & 21 & 21 & 22 & 22 & 25 \\
\hline hálózat & 12 & 12 & 17 & 20 & 18 & 28 & 27 \\
\hline egyesület, civil szervezet & 34 & 24 & 26 & 12 & 17 & 19 & 20 \\
\hline alapítvány & 25 & 20 & 21 & 11 & 11 & 13 & 13 \\
\hline egyéni vállalkozás & 22 & 10 & 23 & 18 & 14 & 21 & 11 \\
\hline for-profit társas vállalkozás & 20 & 10 & 20 & 22 & 18 & 21 & 21 \\
\hline non-profit társas vállalkozás & 30 & 16 & 19 & 14 & 23 & 26 & 27 \\
\hline TDM szervezet részeként & 30 & 28 & 23 & 26 & 29 & 26 & 36 \\
\hline virtuális szervezet & 18 & 15 & 8 & 11 & 9 & 13 & 10 \\
\hline társadalmi vállalkozás & 26 & 17 & 13 & 6 & 11 & 9 & 12 \\
\hline
\end{tabular}

\section{Következtetések, javaslatok}

Egy dolog közös a fent bemutatott esetekben: olyan térségeket mutatnak be, melyek jelentős turisztikai adottságokkal rendelkeznek - az első egy periférikus helyzetü, hátrányos térség, a második egy megye, ahol jelentős ugyan a belföldi és beutazó turizmus, de borturizmusa nem ismert - ugyanakkor nincs egy olyan koordináló és menedzsment szervezet, mely a sikeres és versenyképes müködést tudná biztosítani.

A bemutatott szakértöi kérdőív eredményeképpen arra a megállapításra jutottam, hogy ez a menedzsment szervezet különféle formákban is elképzelhetö, hovatovább az is lehetséges, hogy az útvonal-fejlesztés különböző fázisaiban is eltérő formában müködjön. Az 1. táblázat adatai szerint a legalkalmasabb szervezeti forma egy TDM szervezet része / ága, vagy egy non-profit társaság lenne, mindkettő igen erős kapcsolatot és együttmüködést jelent egy térség minden érintettje (stakeholdere) között.

A társadalmi vállalkozás, mint lehetséges forma, szintén megjelent a lehetőségek között, bár nem kapott annyi javaslatot (említést) mint más formák, azonban ez azt is jelenti, hogy bizonyos térségekben, ahol a turizmusfejlesztés egyben a helyi közösségek fejlesztését, erősítését, munkahelyteremtést, korábban egymástól távol lévő csoportok, szereplők közötti új típusú párbeszédet is jelent, a társadalmi innovációs megoldások jól hasznosíthatók. Az első esetben, a csereháti térségben, ez az együttmüködés kiterjeszthető a helyi termék előállítókra is, így integrálható a mezőgazdaság, kézművesség és gasztronómia is. A 3. ábrával a társadalmi vállalkozás lehetséges szerepeit kívántam bemutatni. 


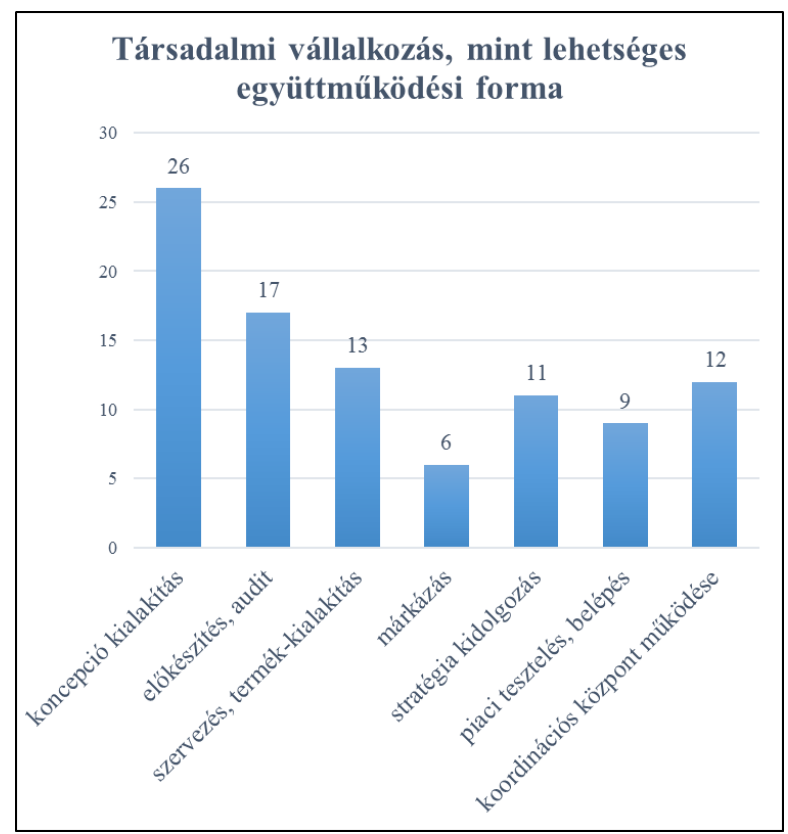

3. ábra. A társadalmi vállalkozás lehetséges szerepei a turizmusfejlesztésben

A társadalmi típusú együttmüködés különösen hangsúlyos az útvonal-alapú fejlesztések elökészítési fázisában, amely annak jelentőségét támasztja alá, mennyire fontos egy térség valamennyi szereplöjét bevonni. Ugyanakkor, speciális ismereteket igénylő tevékenységek, mint pl. a márkázás és a marketing, más, professzionálisabb formákat igényelnek. Visszautalva az 1. táblázat adataira, ahol láthatjuk, melyik fázisban melyik formáció érte el a legmagasabb értéket, arra juthatunk, hogy az útvonal-alapú turizmusfejlesztés egyben egy dinamikus szervezet-fejlesztést is jelent. A bemutatott esetekkel az volt a szándékom, hogy a turizmus más területeiben rejlö lehetőségeket is bemutassam, mint pl. az indiai tea turizmus, vagy az európai katonai örökség hasznosítása, melyeket kevesen ismernek, ugyanakkor kiemelkedő örökségi és helyi értéket képviselnek, autentikus élmények lehetőségével.

\section{Irodalom}

[1] Alkier, R., Milojica, V., Roblek, V. (2015). A holistic framework for the development of a sustainable touristic model. International Journal of Markets and Business Systems, 1(4), 366387. https://doi.org/10.1504/IJMABS.2015.074213

[2] Alkier, R., Milojica, V., Roblek, V. (2017). Challenges of the social innovation in tourism. Tourism in Southern and Eastern Europe, 4, 1-13. https://doi.org/10.20867/tosee.04.24

[3] Benedek, J., Kocziszky, Gy., Veresné, S. M., Balaton, K. (2016). Generating and measuring regional social innovation. 'Club of Economics in Miskolc' TMP, 12, Special Issue, 14-25. https://doi.org/10.18096/TMP.2016.02.02

[4] Benevides, S. L. M., Filho, F. S. P., Madeira, M. J. A., Sakuno, I. Y. T., Arenhardt, V. (2018). Social innovation by tourism strategy in the Western Amazon. International Journal of Advanced Engineering Research and Science, 5(3), 78-92. https://doi.org/10.22161/ijaers.5.3.12

[5] Boswijk, A., Thijsen, T., Peelen, E. (2005). A new perspective on the experience economy: Meaningful experiences. The European Centre for the Experience Economy, The Netherlands. 
[6] Briedenhann, J., Wickens, E. (2004). Tourism routes as a tool for the economic development of rural areas - vibrant hope or impossible dream? Tourism Management, 25, 71-79. https://doi.org/10.1016/S0261-5177(03)00063-3

[7] Butler, R., Hinch, T. (2007). Tourism and indigenous peoples: Issues and implications. Routledge. London https://doi.org/10.4324/9780080553962

[8] DeBakker, F. G., Groenewegen, P., Den Hond, F. (2005). A bibliometric analysis of 30 years of research and theory on corporate social responsibility and corporate social performance. Business \& Society, 44(3), 283-317. https://doi.org/10.1177/0007650305278086

[9] Dorado, S. (2013). Small groups as context for institutional entrepreneurship: An exploration of the emergence of commercial microfinance in Bolivia. Organisation Studies, 34(4), 533-557. https://doi.org/10.1177/0170840612470255

[10] European Commission (2011). Europe 2020 Flagship initiative - Innovation Europe. DG for Research and Innovation, Communication brochure

[11] European Commission (2013). Guide to Social Innovation, ec.europa.eu/growth/industry/innovation/policy/social_en, 06.10.2019

[12] Gonda, T., Bencsikné, A. J., Pálfi, A. (2016a). Tematikus utak jellemzöi és azok szerepe a turisztikai termékfejlesztésben. Tudásmenedzsment 17(1), 228-241. http://kpvk.pte.hu/sites/kpvk.pte.hu/files/tudasmenedzsment_xvii1.pdf\#page=228, letöltve: 2017. 09.20.

[13] Gonda, T. (2016b). https://www.tankonyvtar.hu/hu/tartalom/tamop425/0051_Turisztikai_termek tervezes_ es_fejlesztes/ch08.html

[14] Hall, C. M., McArthur, S. (1998). Integrated heritage management. Stationery Office, London

[15] Howard-Grenville, J., Buckle, S. J., Hoskins, B. J., George, G. (2014). Climate change and management, Academy of Management Journal, 57(3), 615-623. https://doi.org/10.5465/amj.2014.4003

[16] Kovács, D. (2014). Élmény, élménygazdaság, élménytársadalom és turizmus. Turizmus Bulletin, 16(3-4), 40-48.

[17] Light, D., Prentice, R. (1994). Market-based product development in heritage tourism. Tourism Management, 15(1), 27-36. https://doi.org/10.1016/0261-5177(94)90024-8

[18] Lourens, M. (2007). The underpinnings for successful route tourism development in South Africa. Dissertation for Masters Degree of Tourism, University of Witwatersrand, Johannesburg

[19] Majdoub, W. (2010). Analyzing cultural routes from a multidimensional perspective. AlmaTourism, 2, 29-37.

[20] Martorell-C, A. (2003). Cultural routes: Tangible and intangible dimensions of cultural heritage. ICOMOS www.icomos.org

[21] Meyer, D. (2004). Tourism routes and gateways: Key issues for the development of tourism routes and gateways and their potential for pro-poor tourism. Overseas Development Institute

[22] Michalkó, G., Rátz, T. (2005). A kulturális turizmus élmény-gazdaságtani szempontjai. In Enyedi, Gy., Keresztély, K. (Eds.), A magyar városok kulturális gazdasága (pp. 123-141). MTA Társadalo mkutató Központ, Budapest

[23] Mosedale, J., Voll, F. (2017). Social innovation in tourism: Social practices contributing to social development. In Sheldon, P., Daniele, R. (Eds.), Social entrepreneurship and tourism (pp. 101115). Springer International Publishing https://doi.org/10.1007/978-3-319-46518-0_6

[24] Nagy, K.: A tematikus utak helye a turisztikai termékfejlesztésben - paper and presentation, 2012 XIII. RODOSZ Conference, Cluj Napoca, Romania 
[25] Nagy, K. (2013a). Együttmüködési és turisztikai termékfejlesztési modell az örökség-alapú kulturális útvonalak esetében. In Karlovitz (Ed.), Ekonomické štúdie - teória a prax: Gazdasági tanulmányok - elmélet és gyakorlat (566 p. pp. 439-447). Komárno, International Research Institute

[26] Nagy, K.: All roads lead to ... cooperation - Cooperation model for cultural heritage routes with a Swiss case study. $20139^{\text {th }}$ Annual International BATA Conference, Proceedings, Article 28. (2013b) https://doi.org/10.2139/ssrn.3639457

[27] Nagy, K., Piskóti, I.: Individual and social marketing in cultural routes operation, 2013 Conference Proceeding of ICMC, Porto, Portugal, Instituto Portugues de Administracao de Marketing (IPAM), Paper 57. pp. 561-572. https://doi.org/10.2139/ssrn.3639482

[28] Nuryanti, W. (1996). Heritage and postmodern tourism. Annals of Tourism Research, 23(2), 249-260. https://doi.org/10.1016/0160-7383(95)00062-3

[29] OECD (2009). Transforming innovations to address social challenges. www.oecd.org

[30] Pedersen, A.: The possible tangible benefits of working on intangible heritage issues at World heritage sites, 2004 Forum Barcelona 2000, Barcelona

[31] Piskóti, I., Bene, Zs., Marien, A., Nagy, K., Szakál, Z. (2019). Borút, borturizmus - integrált fejlesztési koncepció, módszertan és menedzsment gyakorlat. Turisztikai és Vidékfejlesztési Tanulmányok, 4(3), 21-35. https://doi.org/10.15170/TVT.2019.04.03.02

[32] Poon, A. (1989). Competitive strategies for a new tourism. In C. Cooper (Ed.), Progress in Tourism, Recreation and Hospitality Management (vol. 7, pp. 91-102). Belhaven, London

[33] Prahalad, C. K., Ramaswamy, V. (2004). The future of competition: Co-creating unique value with customers. Harvard Business School Press, Boston https://doi.org/10.1108/10878570410699249

[34] Puczkó, L., Rátz, T. (2011). Az attrakciótól az élményig. A látogatómenedzsment módszerei. Akadémiai Kiadó, Budapest

[35] Rittel, H., Webber, M. (1973). Dilemmas in a general theory of planning. Public Sciences, 4, 155-169. https://doi.org/10.1007/BF01405730

[36] Richards, G. (2018). Cultural Tourism: A review of recent research and trends. Journal of Hospitality and Tourism Management https://doi.org/10.1016/j.jhtm.2018.03.005

[37] Rogerson, C. M., Rogerson, J. M. (2011). Craft routes for developing craft business in South Africa: Is it a good practice or limited policy option? African Journal of Business Management, 5(30), 11736-11748. https://doi.org/10.5897/AJBM11.1926

[38] Schlüter, R. G. (2012). Promoting regional cuisine as intangible cultural heritage in Latin America. In OECD (2012), Food and the Tourism Experience. https://doi.org/10.1787/9789264171923-7-en

[39] Schrempf, J. (2014). A social connection approach to corporate responsibility: The case of the fast-food industry and obesity. Business \& Society, 53, 300-332. https://doi.org/10.1177/0007650312449577

[40] Sloan, P., Legrand, W., Simons-Kaufmann, C. (2014). A survey of social entrepreneurial community based hospitality and tourism initiatives in developing economies: a new business approach for industry. Worldwide Hospitality and Tourism Themes, 6(1), 51-61. https://doi.org/10.1108/WHATT-11-2013-0045

[41] Stanford Business School, (2017). https://www.gsb.stanford.edu/facultyresearch/centersinitiatives/csi /defining-social-innovation

[42] Stasiak, A. (2013). Tourist product in experience economy. Tourism, 23(1), 27-35. https://doi.org/10.2478/tour-2013-0003 
[43] Swarbrooke, J. (1994). The future of the past: Heritage tourism in the $21^{\text {st }}$ Century. In Seaton, A. V. (Ed.), Tourism: The State of the Art. John Wiley and Sons, Chichester, England

[44] Telfer, D. J. (2001). Strategic alliances along the Niagara Wine Route. Tourism Management, 22, 21-30. https://doi.org/10.1016/S0261-5177(00)00033-9

[45] Zeppel, H. (2006). Indigenous ecotourism: Sustainable development and management, Cabi: Wallingford https://doi.org/10.1079/9781845931247.0000

[46] Zietsma, C., Lawrence, T. B. (2010). Institutional work in the transformation of an organisational field: The interplay of boundary work and practice work. Administrative Science Quarterly, 55, 189-221. https://doi.org/10.2189/asqu.2010.55.2.189 